\title{
The in-vitro effects of white henna addition on the Candida albicans adhesion and physical properties of denture base resin
}

\section{Purpose}

This in-vitro study evaluated and compared the effect of white henna (WH) and natural henna $(\mathrm{NH})$ addition on Candida albicans adhesion and physical properties of the denture base material.

\section{Materials and Methods}

A total of 243 acrylic resin specimens (9 per group) were divided as follows: 81 for flexural strength, 81 for Candida albicans adherence test, and 81 for surface roughness, translucency, and hardness. Heat-polymerized acrylic resin specimens were prepared by adding $0.5,1.0,1.5$, or 2.0 wt $\%$ of $\mathrm{WH}$ or $\mathrm{NH}$. Candida albicans adhesion was determined using direct culture and slide count methods. Flexural strength, surface roughness, hardness, and translucency were measured using the three-point bending test, profilometer, Vickers hardness test, and spectrophotometer, respectively. ANOVA and post hoc Tukey's tests were performed for data analysis.

\section{Results}

Addition of $0.5 \% \mathrm{WH}, 1 \% \mathrm{WH}$, and $0.5 \% \mathrm{NH}$ to denture base resin significantly decreased Candida albicans adhesion $(\mathrm{p}<0.05)$. WH and $\mathrm{NH}$ significantly decreased the flexural strength and translucency, except $0.5 \% \mathrm{WH}$, and significantly increased surface roughness, except $0.5 \% \mathrm{WH}$ and $0.5 \% \mathrm{NH}$. WH addition showed nonsignificant differences in the hardness, while $\mathrm{NH}$ addition significantly decreased hardness $(p<0.05)$.

\section{Conclusion}

Addition of WH and $\mathrm{NH}$ decreased C. albicans adhesion to PMMA denture base resin. However, flexural strength, translucency, and surface roughness were adversely affected, particularly at higher concentrations. Hardness was reduced with $\mathrm{NH}$ only.

Keywords: Antifungal agent, Candida albicans; Dental prosthesis, Henna, Physical properties

\section{Introduction}

Polymethylmethacrylate (PMMA) was introduced as a denture base material due to its ease of fabrication, low cost, esthetics, ease of repair, and relatively low toxicity (1). However, the use of the denture intra-orally changes the bio-environment and paves the way for the deposition of biofilms (2). The porous and irregular surfaces of acrylic resins favor microbial adhesion, accumulation, and colonization, which are determining factors in the majority of oral diseases such as candidiasis, sore/burning mouth, and glossodynia (3). Moreover, improper denture hygiene results in debris accumulation and biofilm formation. This leads to inflammatory changes in the underlying mucosa and causes denture-related stomatitis (DS) (4). The role of Candida albicans (C. albicans) in the development of DS is associated with pathogenic overgrowth of Candida on denture sur-

\author{
Mohammed M. Gad' ${ }^{1}$, \\ Mouna Al-Sunni ${ }^{2}$, \\ Abrar Al-Shayeb² (1), \\ Reyam Al-Namasy² (1), \\ Zainab Al-Nassir ${ }^{2}$ (1), \\ Soban Q. Khan ${ }^{3}$
}

ORCID IDs of the authors: M.M.G. 0000-0003-3193-2356; M.A.S. 0000-0003-3237-2290; A.A.S. 0000-0002-7879-2904; R.A.N. 0000-0003-0120-1579; Z.A.N. 0000-0002-5029-8437; S.Q.K. 0000-0002-8573-3080

'Department of Substitutive Dental Sciences, College of Dentistry, Imam Abdulrahman Bin Faisal University, Dammam, Saudi Arabia

${ }^{2}$ College of Dentistry, Imam Abdulrahman Bin Faisal University, Dammam, Saudi Arabia

${ }^{3}$ Department of Dental Education, College of Dentistry, Imam Abdulrahman Bin Faisal University, Saudi Arabia Corresponding Author: Mohammed Moustafa Ahmed Gad

E-mail:mmjad@iau.edu.sa

Received: 3 July, 2020 Revised: 18 September, 2020 Accepted: 22 December, 2020

DOI: 10.26650/eor.20210033 
faces and the oral mucosa, which is widely accepted as an etiological factor $(5,6)$.

The therapeutic strategies currently used to overcome these fungal infections are topical and/or systemic antifungal agents, topical antiseptics, and disinfectants (5). A commonly used antifungal agent known to be an effective treatment of DS is nystatin. However, nystatin is toxic and assists in the development of resistant strains of C. albicans (7). Unfortunately, the recurrence of DS may happen due to the short-acting effects of antifungal medications and the low salivary flow rate, making careful cleaning and disinfection of the denture post antifungal treatment crucial $(7,8)$. This led researchers to adopt more incorporative approaches of natural extract-based antifungal agents into the acrylic resin of the denture base (9).

Several natural extract-based antifungal agents products could prevent DS (10-15). These products were found to be less costly, less toxic, and had reduced ability to produce resistant strains compared to pharmaceuticals $(10,11)$. One of these natural antimicrobial products that could be incorporated into denture base is henna $(12,13)$. Many studies have found that henna has an antifungal effect and could be used to treat fungal infections as a substitute to pharmaceuticals $(16,17)$. Henna has been used in many cultures for the health and wellness of skin and hair, and for the treatment of body lesions caused by fungal infections for thousands of years. However, allergic reactions were found to be one of its side effects. Although few cases have been reported, it was declared that henna carries no genotoxic risk, as confirmed by Yusuf et al. (18-20).

In a study conducted by Nawasrah et al. (14), henna was used as an antifungal agent to prevent the occurrence of DS. This study recommended the use of henna in low concentrations, as high concentrations had an adverse effect on the denture's physical properties, namely color changes (21). Its incorporation in acrylic resin has provided a denture base with antifungal efficacy to control C. albicans proliferation (14). However, discoloration of the final product has limited its use. White henna (WH) is a completely synthetic material that originated in the 1970s. According to the manufacturer, WH is a dust powder and is composed of talcum, titanium dioxide, calcium carbonate, and menthol. The product is synthesized to bleach body hair and skin complexion. It is also used as a scrub to remove dead/damaged skin cells. The material also has the ability to withstand temperatures above $200{ }^{\circ} \mathrm{C}(22)$. To the best of our knowledge, the effect of WH on denture base resin has not been investigated in the literature. We aimed to investigate the effect of WH on C. albicans adhesion as well as the physical properties of PMMA denture base material in comparison to a PMMA/NH composite. First, we propose that $\mathrm{WH}$ addition has antifungal effect. Second, we postulate that $\mathrm{WH}$ addition has no effect on the physical properties of PMMA and can be used as an alternative to $\mathrm{NH}$ for DS prevention.

\section{Materials and Methods}

\section{Study design}

A prior power analysis revealed that a total of 243 specimens $(n=9)$ were needed to adequately detect the differ- ences between $\mathrm{WH}$ and $\mathrm{NH}$ at different concentrations and quantify their effect on the tested properties of modified denture base resin. In accordance with ADA specification No. 12 for denture base polymer, metal molds were prepared in dimensions of $65 \times 10 \times 2.5 \mathrm{~mm}$ for the assessment of flexural strength $(n=81)$ (23). For C. albicans adherence test $(n=$ $81)$, surface roughness, hardness, and translucency $(n=81)$, the dimensions of the specimens were $10 \times 20 \times 2.5 \mathrm{~mm}$. This resulted in a total of 243 specimens of heat-polymerized acrylic resin. The specimens were divided into 9 groups $(n=9)$ according to filler concentration (Table 1$)$. The control group consisted of unmodified acrylic resin, while the other eight tested groups were prepared by addition of either type of henna at different concentrations $(0.5 \%, 1.0 \%, 1.5 \%$, or 2.0 wt\%) to acrylic powder (Major base 20, Major Prodotti Dentari, SPA, Italy).

\section{White henna addition}

WH (white henna, facial bleaching for face and neck, small size - 8850748038009) is a product that has obtained proper registration by the Ministry of Health. Licensed by FDA under registration number por 3/2541 and through por 4/2541. Natural extract of $\mathrm{NH}$ (Yamani henna powder, Harazi), was also used in the current study $(14,24)$. An electronic scale was used to weigh the $\mathrm{WH}$ or $\mathrm{NH}$, which were added separately to the PMMA powder in plastic beakers and mixed for 1 min. Next, they were mixed with PMMA powder and stirred in a blender at a rotating speed of $400 \mathrm{rpm}$ for $30 \mathrm{~min}$ to achieve an equal distribution of henna within the acrylic powder.

\section{Denture base resin preparation}

Polymerization was carried out according to the method specified by the manufacturer and as prescribed in a previous study (25). After complete polymerization, the specimens were retrieved and finished by using a tungsten carbide bur (HM 79GX-040 HP; Meisinger) at 18,000 rpm followed by progressively finer cylindrical silicon resin burs (FINOPOL Polishers, 64830, LABOSHOP GmbH, Germany). Similar to the conventional method of denture polishing, only the cameo surfaces were polished by using a polishing cloth disc (TexMet C10in, 42-3210, Buehler GmbH, Germany) on a polishing machine (Metaserve 250 grinder-polisher, Buehler, Germany) at $100 \mathrm{rpm}$ for five minutes under wet conditions $(26,27)$. After ultrasonic cleaning, the specimens were stored for one week at $37^{\circ} \mathrm{C}$ in distilled water that was changed daily to reduce residual monomers (28).

For the $C$. albicans adherence assay, specimens were sterilized with $70 \%$ alcohol then cleaned ultrasonically with sterilized distilled water. They were then incubated at $37{ }^{\circ} \mathrm{C}$ for two days in artificial saliva containing 2,000,000 C. albicans cells (ATCC 10231). The specimens were later washed and evaluated for attached and proliferated C. albicans. The specimens were incubated in a broth at $37^{\circ} \mathrm{C}$ for $48 \mathrm{~h}$ after washing each specimen three times with phosphate-buffered saline (PBS). The broth was vibrated using a vortex followed by centrifugation of the tubes containing the specimens to yield a concentrated pellet of $C$. albicans. Later, two methods to count the number of adhered $C$. albicans to acrylic resin sample were used for each specimen. 


\section{Direct culture method - colony forming unit (CFU)}

A $10 \mathrm{ml}$ amount of each pellet was taken, serially diluted, and spread on a petri dish. The petri dish was incubated at $37^{\circ} \mathrm{C}$ for $48 \mathrm{~h}$. Colonies of C. albicans were counted using a marker pen counter (colony counter "Scienceware- bel-art products,"Wayne, NJ, USA) in the quadrant where acceptable growth was noted and corrected for the dilution factor (14).

\section{Slide count method}

The collected candida pellets were placed on a slide count (Nebauer Slide Counter "Chambers-Marienfeld") after adding $2.5 \mathrm{ml}$ of $0.4 \%$ solution of trypan blue in phosphate (MP-Biomedicals) to $7.5 \mathrm{ml}$ of each sample for microscopic evaluation. The trypan blue stain can differentiate between dead and living C. albicans; dead cells usually appear blue in color while living cells appear transparent with a blue border. Using light microscope at low magnification (10X), the number of $C$. albicans was counted. The slide count usually contained four main squares; each is divided into 16 squares. C. albicans was counted in two main squares and multiplied by two to get the total number of Candida on the slide.

\section{Physical properties}

To determine the flexural strength, fracture load was measured using a three-point bending test on a universal testing machine (Instron, Model 2519-106, Norwood, MA, USA). Each specimen was placed on a 3-point flexure apparatus where the support span was $50 \mathrm{~mm}$. Load was applied at the midpoint of the prepared area with a crosshead speed of $5 \mathrm{~mm} / \mathrm{min}$ until the specimen fractured, and the maximum load at fracture was recorded. In order to calculate the flexural strength value of each specimen, the following formula was used: $F S=3 W L / 2 b d^{2}$ where FS is the flexural strength (MPa), $b$ is the fracture load $(\mathrm{N}), W$ is the distance between the two supports, $d$ is the specimen width, and $L$ is the specimen thickness.

The surface roughness value $\left(\mathrm{R}_{\mathrm{a}}, \mathrm{mm}\right)$ was determined using a non-contact optical profilometer (Contour GT, Bruker Nano gmbH, Berlin, Germany). A linear variable differential transformer was installed to measure the surface morphology, while the numerical values of the surface profile were calculated on a computer to obtain the $R_{a}$. Three readings per specimen surface were measured (one at a midpoint and two at the margins) on each of the nine specimens per group, and the average $R_{a}$ was recorded.

The hardness test was conducted using its corresponding tester (Wilson Hardness, ITW Test \& Measurement GmbH, Shanghai, China) equipped with a Vickers diamond. An indenter (25-gf load) was applied for $30 \mathrm{~s}$ per specimen; the hardness values were digitally recorded for each specimen.

A reflectance value was measured using a spectrophotometer. A small size $(10 \times 7.5 \mathrm{~mm})$ of aperture viewing area was selected. The spectrophotometer was calibrated using the provided white tile and black trap following the manufacturer's recommendations. Each specimen was stabilized against the port, supported at the back by a white or black reference material with the support arm closed. Color measurements of the coordinates $\left(L^{*}, a^{*}, b^{*}\right)$ of the CIE system were made for every disc against each background. Three readings were made for each specimen and the average was automatically presented by the software. Data was tabulated and translucency was calculated using the following equation TR $=\left[\left(L^{*} \text { white }-L^{*} \text { black }\right)^{2}+\left(a^{*} \text { white }-a^{*} \text { black }\right)^{2}+\right.$ $\left.\left(b^{*} \text { white }-b^{*} \text { black }\right)^{2}\right]^{1 / 2}(26)$.

\section{Statistical analysis}

Normality in the data set was checked using a Shapiro-Wilk test. The test outcome provided insignificant $p$-values, proving that the data were normally distributed. Hence, statistical tests used for further analysis were parametric tests. One-way Analysis of variance (ANOVA) was conducted to determine the effects of white henna and natural henna on C. albicans adhesion, flexural strength, surface roughness, hardness, and translucency of the modified PMMA denture base resin. Tukey's honestly significant difference (HSD) post hoc test was used to determine differences in measurements between the different denture base materials. The correlation between measurements was tested using Pearson correlation analysis. For all comparisons, statistical significance difference was accepted to be $\mathrm{p}<0.05$.

\section{Results}

ANOVA was used to test the overall significance of all properties between all groups (Table 2). After obtaining significant $p$-values from both $\mathrm{WH}$ and $\mathrm{NH}$, pairwise comparisons were done using Tukey's HSD post hoc test (Table 3 and 4). Means, standard deviations, and statistical significances of Candida adhesion are summarized in Table 3. The results showed that the amount of C. albicans adhesion varied depending on the type of henna and their concentrations according to the variance analysis $(p<0.05)$ (Table 3 ).

In the direct culture method (Figures 1 and 2), Figure 2 showed that the addition of $0.5 \% \mathrm{NH}$ and $0.5 \% \mathrm{WH}$ significantly decreased $C$. albicans adhesion in comparison to the control group $(p<0.001)$ and had a value of $(1007.2 \pm 44.1)$ and (561.1 \pm 17.0$)$, respectively. However, henna concentrations of more than $0.5 \%$, significantly increased Candida adhesion in comparison to the control group $(p<0.001)$. When utilizing the slide count method, it was noted that concentrations of $0.5 \%$ and $1.0 \%$ of the $\mathrm{NH}$ groups and $0.5 \%$ of the WH groups significantly decreased the $C$. albicans adhesion compared to the control group ( $p<0.001)$, $(p<$ $0.001)$, and $(p<0.001)$ by values of $(2268 \pm 139.7),(3207 \pm$ $132.5)$ and (1920.2 \pm 69.5$)$, respectively. Other concentration groups (more than $0.5 \% \mathrm{NH} \& 1.0 \% \mathrm{WH}$ ) showed a significant increase in C. albicans adhesion compared to the control group $(p<0.01)$.

Between the $\mathrm{NH}$ and WH groups, a significant difference ( $p$ $<0.001$ ) was found between all concentration groups except between $1.0 \% \mathrm{NH}$ and $1.5 \% \mathrm{WH}(p=0.18)$ groups in terms of direct count. In addition, no significant differences were noted between $0.5 \% \mathrm{NH}$ and $1.5 \% \mathrm{NH}(p=0.994)$ as well as $0.5 \% \mathrm{NH}$ and $1.5 \% \mathrm{WH}(p=0.999)$, or between $1.5 \% \mathrm{NH}$ and $1.5 \% \mathrm{WH}(p=0.827)$ in terms of slide count.

One-way ANOVA revealed $\mathrm{NH}$ and $\mathrm{WH}$ addition affected flexural strength (Table 2). The results showed that addition of $\mathrm{NH}$ and $\mathrm{WH}$ showed a statistically significant decrease in 
the flexural strength in comparison to the control group $(p<0.001)$, except for the $0.5 \% \mathrm{WH}$ group as it showed the highest FS value $(83.09 \pm 0.98 \mathrm{MPa})$ (Table 4). Comparing $\mathrm{NH}$ groups, a significant decrease in FS was found between all groups $(p<0.001)$. FS decreased as $\mathrm{NH}$ concentration increased where $2.0 \% \mathrm{NH}$ had the lowest FS value $(57.61 \pm 1.20$ $\mathrm{MPa}$ ). Similarly, a significant decrease in FS was found between all groups of WH addition ( $p<0.0001)$. FS decreased as WH concentration increased where $2.0 \% \mathrm{WH}$ had the lowest FS value $(59.5 \pm 1.02 \mathrm{MPa})$. When comparing the $\mathrm{NH}$ and WH groups the $\mathrm{NH}$ and $\mathrm{WH}$ groups, significant differences were found between all groups except $0.5 \% \mathrm{NH}$ and $1.0 \%$ WH $(p \approx 1.0)$ and between $1.0 \% \mathrm{NH}$ and $2.0 \% \mathrm{WH}(p=0.993)$.

One-way ANOVA revealed that $\mathrm{NH}$ and $\mathrm{WH}$ addition significantly affected surface hardness $(F=12.978, p<0.001)$ (Table 2). The mean surface hardness and standard deviation of tested groups are summarized in Table 4. In comparison to the control group, the results showed a significant decrease in the hardness of all $\mathrm{NH}$ groups and $2.0 \% \mathrm{WH}$ addition ( $p$ $<0.001)$ while there was no statistical significant difference at $0.5 \% \mathrm{WH}(p=0.601), 1.0 \% \mathrm{WH}(p=0.416)$ and $1.5 \% \mathrm{WH}$ $(p=0.221)$. Additionally, the highest hardness value was reported in the control group (38.67 $\pm 1.33 \mathrm{VHN})$. The results showed that the addition of $\mathrm{NH}$ to PMMA denture base resin significantly decreased the hardness values in comparison to the control group $(p<0.001)$ while WH addition showed no significant difference in hardness values $(p>0.05)$, except the $2 \% \mathrm{NH}$ group $(p=0.022)$.

Comparing $\mathrm{NH}$ groups, insignificant differences in hardness were found between all groups. The hardness value was lowest in the $1.0 \% \mathrm{NH}$ group $(31.05 \pm 2.03 \mathrm{VHN})$. In between WH groups, insignificant differences in hardness was found between all groups $(p>0.05)$. The lowest hardness value was observed in the $2.0 \% \mathrm{WH}$ group $(35.39 \pm 2.28$ VHN). In comparison, between the $\mathrm{NH}$ and WH groups, insignificant differences were found between the $0.5 \% \mathrm{NH}$ and $2.00 \% \mathrm{WH}(p=0.352)$ and the $0.5 \% \mathrm{NH}$ and all $\mathrm{NH}$ groups, where the $p$-values were: $1.0 \% \mathrm{NH}(p=0.334), 1.5 \% \mathrm{NH}(p=$ $1.00)$, and $2.0 \% \mathrm{NH}(p=0.809)$. Also, insignificant differences were found between $1.00 \% \mathrm{NH}$ and $1.5 \% \mathrm{NH}(p=413), 1.5 \%$ $\mathrm{NH}$ and $2.0 \% \mathrm{NH}(p=0.744)$, and $1.5 \% \mathrm{NH}$ and $2.0 \% \mathrm{WH}(p=$ 0.289 ). There were insignificant differences found between $2.0 \% \mathrm{NH}$ and all WH groups, where the values were: $0.5 \% \mathrm{WH}$ $(p=0.601), 1.0 \% \mathrm{WH}(p=0.416), 1.5 \% \mathrm{WH}(p=0.221)$, and $2.0 \%(p=0.998)$.

One-way ANOVA results showed that $\mathrm{NH}$ and $\mathrm{WH}$ additions significantly increased surface roughness ( $F=177.283$, $p=0.000$ ) (Table 2). In comparison to the control group, Tukey results (Table 4) showed a significant increase in $R_{a}$ with $\mathrm{NH}$ and $\mathrm{WH}$ addition $(p<0.001)$ in all percentages, except for $0.5 \% \mathrm{NH}(p=1.00)$ and $0.5 \% \mathrm{WH}(p=0.999)$ addition groups. Addition of $2.0 \% \mathrm{NH}$ had the highest $\mathrm{R}_{\mathrm{a}}$ value $(0.51 \pm$ $0.03 \mu \mathrm{m})$. When comparing $\mathrm{NH}$ groups, a significant increase in $\mathrm{R}_{\mathrm{a}}$ in all groups was observed $(p<0.001)$. Similarly, between WH groups, a significant increase in $\mathrm{R}_{\mathrm{a}}$ in all groups ( $p<0.001$ ) was noted. $\mathrm{R}_{\mathrm{a}}$ increased as the concentration of $\mathrm{NH}$ and $\mathrm{WH}$ increased where $2.0 \% \mathrm{NH}$ had the highest value $(0.51 \pm 0.03 \mathrm{~mm})$. Non-significant differences were found when $\mathrm{NH}$ and $\mathrm{WH}$ were compared at $0.5 \% \mathrm{NH}$ and $0.5 \% \mathrm{WH}$ $(p=1.00), 1.0 \% \mathrm{NH}$ and $1.0 \% \mathrm{WH}(p=0.999)$, and at $1.5 \% \mathrm{NH}$ and $1.5 \% \mathrm{WH}(p=0.989)$.
One-way ANOVA proved $\mathrm{NH}$ and $\mathrm{WH}$ addition significantly affected translucency ( $F=370.890, p<0.001$ ) (Table 2). As shown in Table 4, a significant decrease in the translucency was found with $\mathrm{NH}$ and $\mathrm{WH}$ additions in comparison to the control group ( $p<0.001)$, except for $0.5 \% \mathrm{WH}(\mathrm{p} \approx 1.00)$; the control group had the highest translucency value (15.82). Comparing NH groups, a significant decrease in translucency was found between all groups $(p<0.001)$. The translucency value decreased as $\mathrm{NH}$ concentration increased and $0.5 \% \mathrm{NH}$ showed the highest translucency $(12.79 \pm 0.61)$ while $2.0 \% \mathrm{NH}$ showed the lowest translucency value $(4.82$ \pm 0.29 ). In between the WH groups, in between WH groups, a significant decrease in translucency was noted between all groups, except for $0.5 \% \mathrm{WH}(p \approx 1.00)$. The translucency value decreased as $\mathrm{WH}$ concentration increased where $2.0 \%$ $\mathrm{WH}$ had the lowest translucency value $(8.17 \pm 0.33)$. Also, non-significant differences were found between $\mathrm{NH}$ and $\mathrm{WH}$ for $0.5 \% \mathrm{NH}$ and $1.0 \% \mathrm{WH}(p=0.093)$ and $1.0 \% \mathrm{NH}$ and $1.5 \%$ $\mathrm{WH}(p=0.342)$.

\section{Discussion}

The incorporation of antifungal agents in polymeric materials is considered a good alternative for slow and prolonged

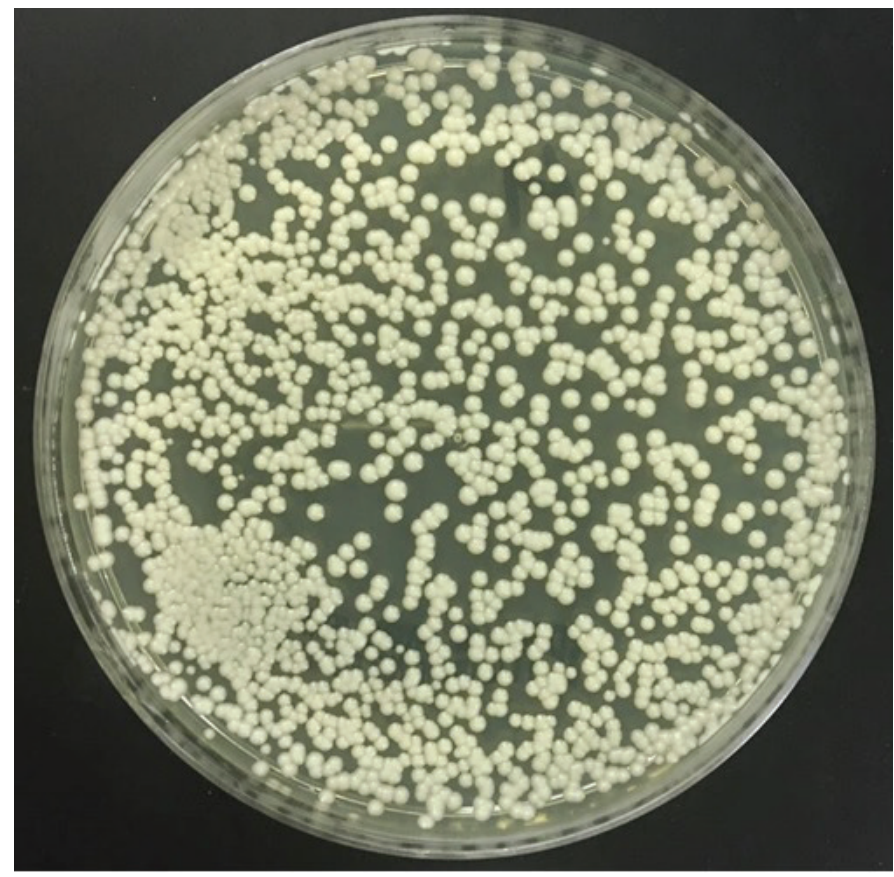

Figure 1. Direct culture method for Candida count - control group (unmodified group).

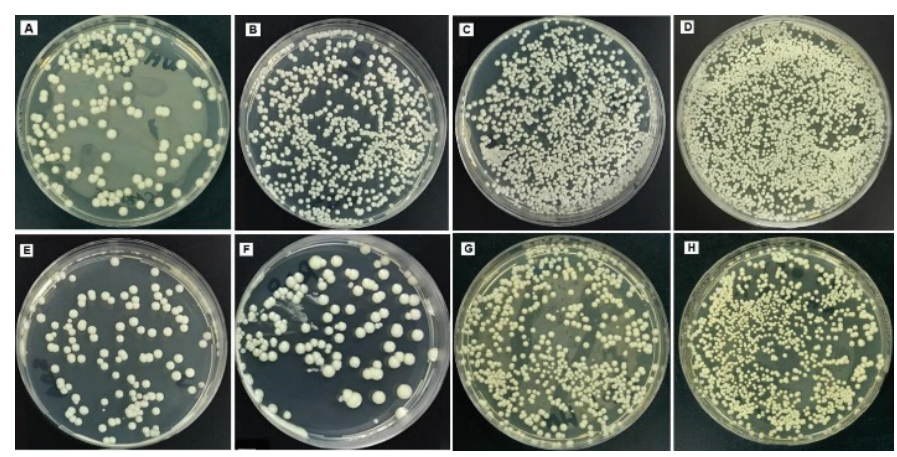

Figure 2. Direct culture method for Candida count - Henna modified groups A-D NH group; E-HWH group. 
drug release in the mouth and may be therapeutically useful against $C$. albicans since it does not depend on patient cooperation $(7,11,12)$. Moreover, it would maintain constant and prolonged contact of the antifungal agent with the oral tissues. It has been reported that a large portion of topical drugs used in fighting DS are lost from the oral cavity during the first three hours due to the diluting effect of saliva, and the cleaning effect generated by movement of the oral musculature that results in possible reduction of the therapeutic effect $(6,8)$. Consequently, henna addition was suggested to be incorporated into denture base materials (21). This study hypothesized that henna has antifungal effects that may aid in the prevention of DS without compromising the denture base's physical and mechanical properties. This was confirmed through our results, which suggest low concentrations of henna can offer an antifungal activity preventing DS; however, it compromises the physical and mechanical

Table 1. Grouping of the specimens according to NH and WH concentrations.

\begin{tabular}{|c|c|}
\hline Group & Specifications \\
\hline Control & Unmodified acrylic resin \\
\hline \multirow{4}{*}{ I Natural Henna (NH) } & Acrylic resin modified with $0.5 \% \mathrm{NH}$ \\
\hline & Acrylic resin modified with $1.0 \% \mathrm{NH}$ \\
\hline & Acrylic resin modified with $1.5 \% \mathrm{NH}$ \\
\hline & Acrylic resin modified with $2.0 \% \mathrm{NH}$ \\
\hline \multirow{4}{*}{ II White henna (WH) } & Acrylic resin modified with $0.5 \% \mathrm{WH}$ \\
\hline & Acrylic resin modified with $1.0 \%$ WH \\
\hline & Acrylic resin modified with $1.5 \% \mathrm{WH}$ \\
\hline & Acrylic resin modified with $2.0 \% \mathrm{WH}$ \\
\hline
\end{tabular}

properties of the denture base to some extent.

Henna is a readily available and cheap powder that has been proven to have some antifungal properties (17). It can be incorporated into the denture's base material in certain concentrations, making it cost effective and able to prevent recurring DS. This method results in what has been called a potential antimicrobial denture base; however, concerns of alterations to the mechanical and physical properties of the denture base rise with such procedure $(14,29)$.

The results of this study have shown that a $0.5 \%$ concentration of either $\mathrm{WH}$ or $\mathrm{NH}$ as well as $1.0 \% \mathrm{WH}$ reduced $\mathrm{C}$.

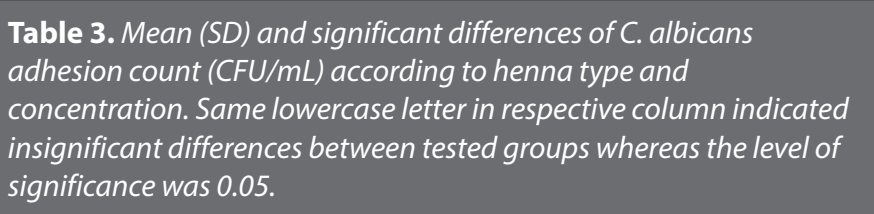

\begin{tabular}{llcc}
\multirow{2}{*}{ Group } & $\%$ & \multicolumn{2}{c}{ Mean(SD) } \\
\cline { 2 - 4 } & & $\begin{array}{c}\text { Direct culture } \\
\text { method }\end{array}$ & Slide Count method \\
\hline Control & 0 & $1348.0(23.8)$ & $3265.0(135.3)$ \\
\hline \multirow{2}{*}{$\mathrm{NH}$} & $0.5 \% \mathrm{NH}$ & $1007.2(44.1)$ & $2268.0(139.7)^{\mathrm{a}, \mathrm{b}}$ \\
\hline & $1.0 \% \mathrm{NH}$ & $2061.4(31.1)^{\mathrm{a}}$ & $3207.0(132.5)$ \\
\hline & $1.5 \% \mathrm{NH}$ & $2313.0(167.3)$ & $5462.0(92.2)^{\mathrm{a}, \mathrm{c}}$ \\
\hline \multirow{3}{*}{$\mathrm{WH}$} & $2.0 \% \mathrm{NH}$ & $3207.0(132.5)$ & $7357(296.4)$ \\
\hline & $0.5 \% \mathrm{WH}$ & $561.1(17.0)$ & $1920.2(69.5)$ \\
\hline & $1.0 \% \mathrm{WH}$ & $1107.1(12.8)$ & $3311.5(105.1)$ \\
\hline & $1.5 \% \mathrm{WH}$ & $1565.2(31.6)^{\mathrm{a}}$ & $4618.5(140.1)^{\mathrm{b}, \mathrm{c}}$ \\
\hline & $2.0 \% \mathrm{WH}$ & $2746.1(114.6)$ & $6706.0(128.9)$ \\
\hline
\end{tabular}

Table 2. ANOVA of direct culture, and slide count tests for Candida adhesion, flexural strength test, hardness test, surface roughness test, and translucency.

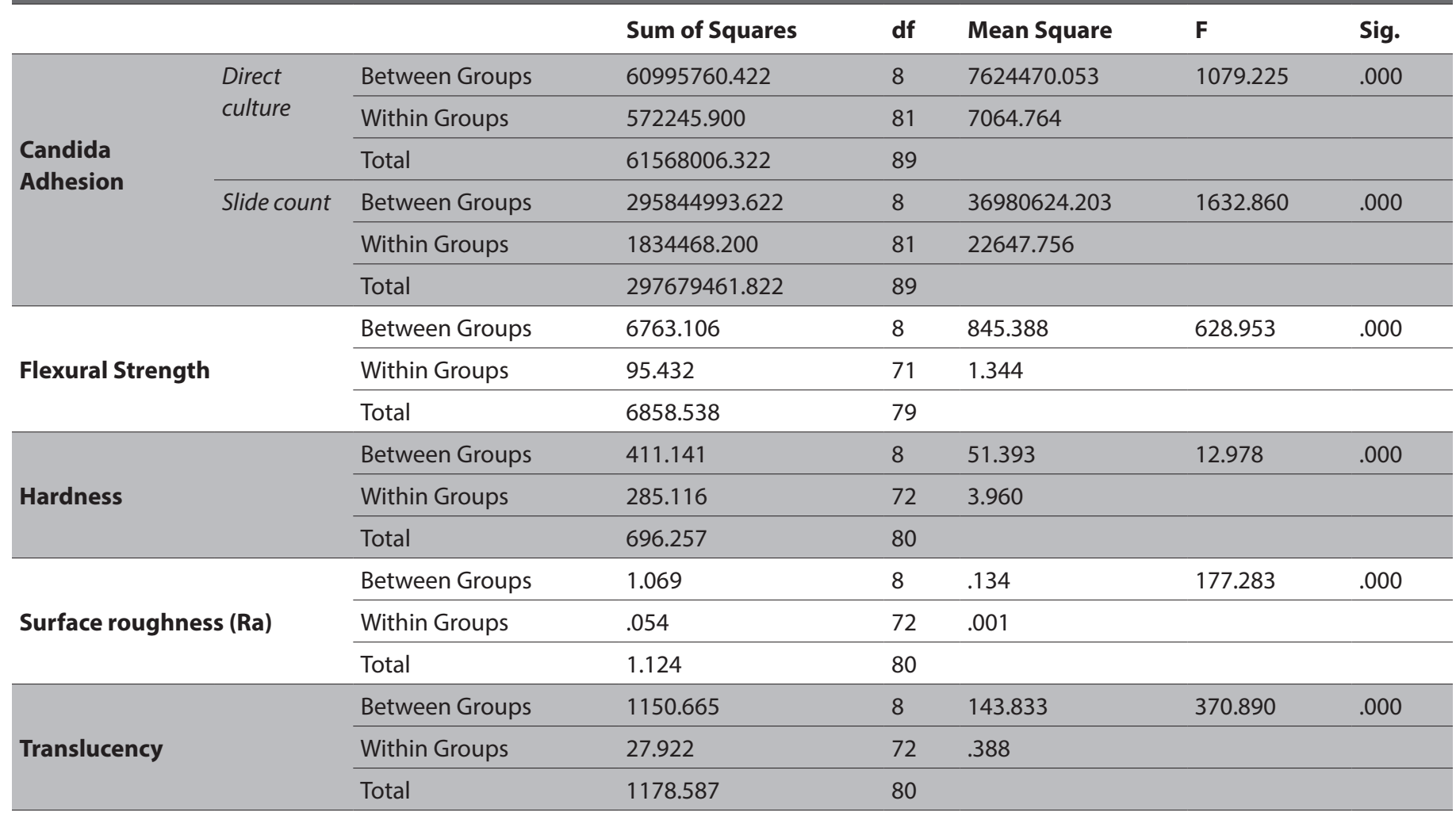


Table 4. Mean (SD) and significant differences of flexural strength, hardness, surface roughness, and translucency of tested specimens according to henna type and concentration.

Mean(SD)

\begin{tabular}{|c|c|c|c|c|c|}
\hline Group & $\%$ & $\begin{array}{l}\text { Flexural strength } \\
\text { (MPa) }\end{array}$ & $\begin{array}{c}\text { Hardness } \\
\text { (VHN) }\end{array}$ & $\begin{array}{l}\text { Surface roughness } \\
\qquad(\mu \mathrm{m})\end{array}$ & Translucency \\
\hline Control & 0 & $82.79(1.78)^{a}$ & $38.67(1.33)^{a}$ & $0.19(0.012)^{a}$ & $15.82(1.1)^{\mathrm{a}}$ \\
\hline \multirow{4}{*}{ NH } & $0.5 \% \mathrm{NH}$ & $79.67(0.68)^{b}$ & $33.23(2.20)^{b}$ & $0.19(0.01)^{a, b}$ & $12.79(0.61)^{b}$ \\
\hline & $1.0 \% \mathrm{NH}$ & $70.80(0.64)^{d}$ & $31.05(2.03)^{b, c}$ & $0.35(0.04)^{c}$ & $10.65(0.65)^{c}$ \\
\hline & $1.5 \% \mathrm{NH}$ & $62.57(1.10)^{c}$ & $33.12(3.04)^{b, c, d}$ & $0.41(0.02)^{d}$ & $5.91(0.52)$ \\
\hline & $2.0 \% \mathrm{NH}$ & $57.61(1.20)$ & $34.72(1.02)^{b, d, e}$ & $0.51(0.03)$ & $4.82(0.29)$ \\
\hline \multirow{4}{*}{ WH } & $0.5 \% W H$ & $83.09(0.98)^{a}$ & $36.52(2.79)^{a, e, f}$ & $0.20(0.01)^{a, b}$ & $15.69(0.51)^{a}$ \\
\hline & $1.0 \% W H$ & $77.77(1.54)^{b}$ & $36.78(0.99)^{a, e, f}$ & $0.35(0.02)^{c}$ & $13.65(0.61)^{b}$ \\
\hline & $1.5 \%$ WH & $71.32(1.10)^{d}$ & $37.12(0.81)^{a, e, f}$ & $0.40(0.02)^{d}$ & $11.33(0.69)^{c}$ \\
\hline & $2.0 \% W H$ & $59.95(1.02)^{c}$ & $35.39(2.28)^{b, d, e, f}$ & $0.46(0.03)$ & $8.17(0.33)$ \\
\hline
\end{tabular}

Same lowercase letter in respective column indicated insignificant differences between tested groups whereas the level of significance was 0.05.

albicans adhesion and subsequently, DS, in accordance with previous studies $(14,16)$. While naphthoquinones are considered to be the main active molecules that give natural henna this antifungal property, the antifungal activity of $\mathrm{WH}$ is gained from its ingredients: talcum, titanium dioxide, calcium carbonate, and menthol (22). These chemicals were able to withstand the high temperatures PMMA is subjected to during curing (22). Further investigations are still required as WH showed over one-fold greater (55.7\%) antifungal activity than $\mathrm{NH}$ at the same concentrations $(0.5 \%)$.

A correlation between surface roughness and C. albicans adhesion and colonization has been reported (30). Surface roughness is an important property of the denture base material that influences plaque and microbial adhesion $(31,32)$. A rough denture surface provides more area for microbial adhesion. In addition, it protects entrapped microorganisms from shearing forces during denture cleaning, making their removal difficult even when using antimicrobial agents (33). According to the findings of the current study, as $\mathrm{NH}$ and $\mathrm{WH}$ concentrations increased, C. albicans colonies increased, and this increase in colonies was proportional to the increase in surface roughness reported with modified groups.

The present study has shown that the addition of $\mathrm{WH}$ or $\mathrm{NH}$ decreases the FS of modified denture base in a direct relation to the filler concentration compared to non-modified denture base. Regardless, the decrease observed in some concentration groups remained above the minimally accepted FS value according to ISO: 1567 standard requirements $(65 \mathrm{MPa})(23,34)$. The groups that met the standard requirement were $0.5 \%, 1.0 \%$, and $1.5 \%$ of $\mathrm{WH}$ as well as the $0.5 \%$ and $1.0 \% \mathrm{NH}$ groups. In alignment with previous reports, the addition of low concentrations $(0.5 \%, 1.0 \%)$ of thymoquinone antifungal agent did not affect the FS of PMMA denture base material (25).

A significant decrease was also noted in the modified denture base hardness value in all $\mathrm{NH}$ groups, which was in agreement with Nawasrah et al., and only the $2.0 \%$ concentration of WH groups (24). Unaffected WH groups may be attributed to the synesthetic constituents of $\mathrm{WH}$, where particles were well distributed and bonded to PMMA. This effect is observed up to $1.5 \%$ concentration, above which resin saturation is attained and hardness is decreased.

The decrease in FS and hardness values may be attributed to the additive in the PMMA denture base material since it interferes with the integrity of the polymer matrix (30). These added particles could be aggregate-forming clusters acting as stress-concentration areas within the matrix $(22,24)$. The weak bond between $\mathrm{NH}$ and the PMMA resin matrix makes the added henna act as an impurity, which resulted in an adverse effect on the degree of conversion. This, in turn, led to an increase in the level of residual unreacted monomer that acted as a plasticizer (22,35).

The oral tissue conditions under the denture base are affected by the surface properties of the denture base. Previous studies have suggested that surface roughness was found to be directly proportional to microorganism attachment to the denture base $(24,32)$. The results of present study showed that that the specimens' $R_{a}$ values significantly increased as the $\mathrm{NH}$ and $\mathrm{WH}$ concentrations increased. The increase in $R_{a}$ values with high henna concentrations might be explained by the presence of some loosely attached particles of $\mathrm{NH}$ and $\mathrm{WH}$ on the resin surface which could easily be removed during the finishing and polishing phases, leaving voids (22).

The maximum acceptable $R_{a}$ of removable prostheses for clinical use is $0.2 \mu \mathrm{m}$ (31). In this study, both $\mathrm{NH}$ and $\mathrm{WH}$ at $0.5 \%$ concentration had lower $R_{a}$ values $(0.19 \mu \mathrm{m})$, which is considered clinically acceptable. This suggests that the limit for addition in relation to $R_{a}$ is $0.5 \%$ for both henna types. Nawasrah et al., studied the effect of $\mathrm{NH}$ addition to PMMA denture base and noted that surface roughness increased as the percentage of henna increased, in consensus with this study (24).

The success of a removable prosthesis relies on the appearance of the denture base in relation to that of the patient's oral mucosa, and the translucency of the material itself. To offer prosthesis with a natural look, the level of translucency is critical. Therefore, it is important to create a harmonious optical property between the removable prosthesis and the underlying mucosa giving a "chameleon" effect, allow- 
ing the underlying soft tissues to show through the PMMA denture base (26). A significant decrease in translucency was noted with $\mathrm{NH}$ and translucency decreased as the concentrations of $\mathrm{NH}$ increased. On the other hand, $0.5 \% \mathrm{WH}$ did not change the translucency in comparison to the control group, yet slight changes in translucency were found in 1.0\% and $1.5 \% \mathrm{WH}$. The difference in the results may be attributed to henna color, where $\mathrm{NH}$ was found to be grey and WH was white. This resulted in different color absorption or reflection ability. Specimens with high concentrations of $\mathrm{NH}$ seemed black in color, while specimens containing high concentrations of WH appeared white.

White henna showed promising results that might help in the prevention of DS even with the alterations of the physical and mechanical properties of PMMA. This can be achieved when adding $\mathrm{WH}$ at $0.5 \%$ and $1.0 \%$ concentrations. An acceptable concentration of $\mathrm{NH}$ was found to be $0.5 \%$, while higher concentrations lead to poor physical and mechanical properties of PMMA. It is recommended that future studies test the antifungal activity of $\mathrm{WH}$ at lower concentrations and its effect on the physical and mechanical properties of PMMA. Further investigation including aging effects such as water immersion, thermal cycling, and the longevity of the antifungal effect would also be very interesting and highly beneficial.

Despite some key foundational successes from which to build on, this in-vitro study also suffered some limitations. We noted the lack of use of other types of denture base materials; the lack of proper simulation of the oral environment, precluding dynamic movements; thermal changes; saliva with prospective $\mathrm{pH}$; and the presence of other microorganisms that may affect the denture base properties and C. albicans adhesion.

\section{Conclusion}

Within the limitations of this study, the following conclusions can be drawn: the addition of $0.5 \%, 1.0 \% \mathrm{WH}$, and $0.5 \%$ $\mathrm{NH}$ to denture base material decreased C. albicans adhesion. However, increased concentrations of either type of henna yielded higher $C$. albicans adhesion. The addition of either type of henna decreased the flexural strength, especially at high concentrations. $\mathrm{NH}$ addition decreased the hardness, while no change in hardness with $\mathrm{WH}$ addition was observed. The addition of $0.5 \% \mathrm{WH}$ or $\mathrm{NH}$ did not affect surface roughness, while higher concentration produced rougher surfaces. $\mathrm{NH}$ addition decreased translucency, while $0.5 \%$ WH addition did not show any changes in translucency.

Türkçe Özet: Beyaz henna ilavesinin protez kaidesi reçinelerine candida albicans tutunması ve fiziksel özelliklerine in vitro etkisi. Amaç: Bu in-vitro çalışmada, protez kaide materyaline beyaz henna $(B H)$ ya da doğal henna ilavesinin (DH) Candida albicans tutunması incelenmiştir. Ayrıca, bu akrilik materyalinin fiziksel özellikleri de değerlendirilmiştir. Gereç ve Yöntem: Toplam 243 akrilik Reçine örneğin (grup başına 9 örnek), 81'i bükülme dayanımını, 81'i Candida albicans tutunumunu, 81'i yüzey pürüzlülüğünü, geçirgenliğini ve sertliğini test etmek için kullanılmıştır. Isı ile polimerime olan akrilikten yapılmış olan örnekler, \% ağırlıkça 0.5, 1.0, 1.5, or 2.0 BH ya da NH içerecek şekilde hazırlanmıştır. Candida albicans tutunumu, direkt kültür ve koloni sayma yöntemleri uygulanarak ölçülmüştür. Bükülme dayanumı, yüzey pürüzlülüğü, sertliği ve geçirgenliği sırası ile üç-nokta bükme testi, profilometre, Vickers sertlik testi, ve spektrofotometre ile ölçülmüştür. Veri analizi için ANOVA ve post hoc
Tukey's testleri kullanılmıştır ( $a=0.05)$. Bulgular: Protez kaide reçinesine $0.5 \%$ BH, $1 \%$ BH, ya da $0.5 \%$ DH ilavesi Candida albicans tutunumunu anlamlı şekilde düşürmüştür $(p<0.05)$. $B H$ ve $D H, 0.5 \%$ lik $B H$ hariç bükülme dayanımı ve geçirgenliği anlamlı şekilde düşürmüş, $0.5 \% \mathrm{BH}$ ve $0.5 \%$ DH haricinde de yüzey pürüzlülüğünü arttırmıştır ( $p<0.05)$. BH ilavesi, sertlikte istatistiksel olarak anlamlı olmayan değişiklikler gösterirken, DH ilavesi sertliği anlamlı olarak azaltmıștır $(p<0.05)$. Sonuç: BH ve $\mathrm{DH}$ ilavesi akrilik protez kaide reçinesine $C$. albicans tutunumunu azaltmaktadır. Fakat, bükülme dayanımı, geçirgenlik ve yüzey pürüzlülüğü üzerinde özellikle yüksek konsantrasyonlarda tam ters etki göstermiştir. Sertlik sadece NH ile azalmıştır. Anahtar Kelimeler: Antifungal ajan, Candida albicans, Dental protez, Henna, Fiziksel özellikler

Ethics Committee Approval: Not required.

Informed Consent: Not required.

Peer-review: : Externally peer-reviewed.

Author contributions: MA, RA and MMG participated in designing the study. $A A$ and $R A$ participated in generating the data for the study. MA, AA,RA and ZA participated in gathering the data for the study. ZA and SQK participated in the analysis of the data. MA, AA and $Z A$ wrote the majority of the original draft of the paper. MA, RA, ZA, MFE and MMG participated in writing the paper. MA, SQK and MMG have had access to all of the raw data of the study. MA, AA, RA, MFE and MMG have reviewed the pertinent raw data on which the results and conclusions of this study are based. All authors have approved the final version of this paper. MA and MMG guarantee that all individuals who meet the Journal's authorship criteria are included as authors of this paper.

Conflict of Interest: The authors had no conflict of interest to declare.

Financial Disclosure: The authors declared that they have received no financial support.

\section{References}

1. Gharechahi J, Asadzadeh N, Shahabain F, et al. Flexural Strength of Acrylic Resin Denture Bases Processed by Two Different Methods. J Dent Res Dent Clin Dent Prospect 2014;8:148-52.

2. Rodriguez LS, Paleari AG, Giro G, et al. Chemical characterization and flexural strength of a denture base acrylic resin with monomer 2-tert-butylaminoethyl methacrylate. J Prosthodont 2013;22:292-7. [CrossRef]

3. Valentini F, Luz MS, Boscato N, et al. Biofilm formation on denture liners in a randomised controlled in situ trial. J Dent 2013;41:420-7. [CrossRef]

4. Campos MS, Marchini L, Bernardes LA, et al. Biofilm microbial communities of denture stomatitis. Oral Microbiol Immunol 2008;23:419-24. [CrossRef]

5. Salerno $C$, Pascale $M$, Contaldo $M$, et al. Candida-associated denture stomatitis. Med Oral Patol Oral Cir Bucal 2011;16:13943. [CrossRef]

6. Dar-Odeh NS, Al-Beyari M, Abu-Hammad OA. The role of antifungal drugs in the management of denture-associated stomatitis. Int Ara j antimicro agents 2012;2:1-5.

7. Bakhshi M, Taheri JB, Shabestari SB, et al. Comparison of therapeutic effect of aqueous extract of garlic and nystatin mouthwash in denture stomatitis. Gerodontology 2012;29:6804. [CrossRef]

8. Garcia-Cuesta C, Sarrion-Pérez MG, Bagán JV. Current treatment of oral candidiasis: A literature review. J Clin Exp Dent 2014;6:57682. [CrossRef]

9. Gad MM, Fouda SM. Current perspectives and the future of Candida albicans-associated denture stomatitis treatment. Dent Med Probl 2020;57:95-102. [CrossRef] 
10. Alavarce RA, Saldanha LL, Almeida NL, et al. The beneficial effect of Equisetum giganteum L. against Candida biofilm formation: new approaches to denture stomatitis. Evidence-Based Complem Alternat Med 2015;2015:939625. [CrossRef]

11. Marcos-Arias $C$, Eraso $E$, Madariaga $L$, et al. In vitro activities of natural products against oral Candida isolates from denture wearers. BMC Complement Altern Med 2011;26:119. [CrossRef]

12. Al-Thobity AM, Al-Khalifa KS, Gad MM, et al. In Vitro Evaluation of the Inhibitory Activity of Thymoquinone in Combatting Candida albicans in Denture Stomatitis Prevention. Int J Environ Res Public Health 2017;14:743. [CrossRef]

13. Hamid SK, Al-Dubayan AH, Al-Awami $\mathrm{H}$, et al. In vitro assessment of the antifungal effects of neem powder added to polymethyl methacrylate denture base material. J Clin Exp Dent 2019;11:170-8. [CrossRef]

14. Nawasrah A, AINimr A, Ali AA. Antifungal effect of henna against Candida albicans adhered to acrylic resin as a possible method for prevention of denture stomatitis. Int J Environ Res Public Health 2016;13:520. [CrossRef]

15. Marcos-Arias C, Eraso $E$, Madariaga $L$, et al. In vitro activities of natural products against oral Candida isolates from denture wearers. BMC Complement Altern Med 2011;26:119. [CrossRef]

16. Tripathi RD, Srivastava HS, Dixit SN. A fungitoxic principle from the leaves of Lawsonia inermis Linn. Experientia 1978;34:51-2. [CrossRef]

17. Yaralizadeh $M$, Abedi $P$, Namjoyan $F$, et al. A comparison of the effects of Lawsonia inermis (Iranian henna) and clotrimazole on Candida albicans in rats. J Mycol Med 2018;28:419-23. [CrossRef]

18. Kandil HH, AlGhanem MM, Sarwat MA, et al. Henna (Lawsonia inermis Linn) inducing haemolysis among G6PD-defcient newborns. A new clinical observation. Ann Trop Paediatr 1996;16:287-91. [CrossRef]

19. Kirkland D, Marzin D. An assessment of the genotoxicity of 2-hydroxy-1, 4-naphthoquinone, the natural dye ingredient of Henna. Mutat Res Genet Toxicol Environ Mutagen 2003;537:18399. [CrossRef]

20. Marzin D, Kirkland D. 2-Hydroxy-1, 4-naphthoquinone, the natural dye of Henna, is non-genotoxic in the mouse bone marrow micronucleus test and does not produce oxidative DNA damage in Chinese hamster ovary cells. Mutat Res Genet Toxicol Environ Mutagen 2004;560:41-7. [CrossRef]

21. Gad MM, Rahoma A, Nawasrah A, et al. Influence of Henna Addition on The Flexural Strength of Acrylic Denture Base Material: An In Vitro Study. ADJ-for Girls 2018;5: 277-83. [CrossRef]

22. Herbst, Heinz, and Urs Stadler. Mixtures of phenolic and inorganic materials with antimicrobial activity. U.S. Patent 6,585,989, July 1, 2003.
23. American Dental Association, Revised American Dental Association Specification N.12 for denture base polymers. J Am Dent Assoc 1975;90:451-8. [CrossRef]

24. Nawasrah A, Gad MM, El Zayat M. Effect of Henna Addition on the Surface Roughness and Hardness of Polymethylmethacrylate Denture Base Material: An in vitro Study. J Contemp Dent Pract 2018;19:732-8. [CrossRef]

25. Gad MM, Al-Thobity AM, Fouda SM, et al. Flexural and Surface Properties of PMMA Denture Base Material Modified with Thymoquinone as an Antifungal Agent. J Prosthodont 2020;29:243-50. [CrossRef]

26. Gad MM, Abualsaud R, Rahoma A, et al. Double-layered acrylic resin denture base with nanoparticle additions: An in vitro study. J Prosthet Dent 2020;S0022-3913:30555-2. [CrossRef]

27. Al-Harbi FA, Abdel-Halim MS, et al. Effect of Nanodiamond Addition on Flexural Strength, Impact Strength, and Surface Roughness of PMMA Denture Base. J Prosthodont 2019;28:41725. [CrossRef]

28. Murat $\mathrm{S}$, Alp G, Alatalı C, et al. In Vitro Evaluation of Adhesion of Candida albicans on CAD/CAM PMMA-Based Polymers. J Prosthodont 2019;28:873-9. [CrossRef]

29. Sivakumar I, Arunachalam KS, Sajjan S, et al. Incorporation of antimicrobial macromolecules in acrylic denture base resins: $\mathrm{A}$ research composition and update. J Prosthodont 2014;23:28490. [CrossRef]

30. Kanie T, Arikawa H, Fujii $\mathrm{K}$, et al. Physical and mechanical properties of PMMA resins containing gamma methacryloxypropyltrimethoxysilane. J Oral Rehabil 2004;31:166-71. [CrossRef]

31. AlBin-Ameer MA, Alsrheed MY, Aldukhi IA, et al. Effect of Protective Coating on Surface Properties and Candida albicans Adhesion to Denture Base Materials. J Prosthodont 2020;29:806. [CrossRef]

32. Fouda SM, Gad MM, Ellakany P, et al. The effect of nanodiamonds on Candida albicans adhesion and surface characteristics of PMMA denture base material - an in vitro study. J Appl Oral Sci 2019;27:20180779. [CrossRef]

33. Pereira-Cenci T, Del Bel Cury AA, Crielaard W, Ten Cate JM. Development of Candida-associated denture stomatitis: new insights. J Appl Oral Sci 2008;16:86-94. [CrossRef]

34. Zappini G, Kammann A, Wachter W. Comparison of fracture tests of denture base materials. J Prosthet Dent 2003;90:578-85. [CrossRef]

35. Aydogan Ayaz E, Durkan R, Bagis B. The effect of acrylamide incorporation on the thermal and physical properties of denture resins. J Adv Prosthodont 2013;5:110-7. [CrossRef] 